\author{
M. V. Zarichkova, O. M. Dolzhnikova, T. F. Muzika \\ National University of Pharmacy
}

\title{
JUSTIFICATION FOR THE SYSTEM OF SOCIAL PASSPORT INDICATORS IN A PHARMACY INSTITUTION
}

The aim of the study is to justify the need to introduce social standards in pharmacy institutions and to determine the methodology for estimation of the social passport of a pharmacy by calculating the criteria, which characterize the social structure of the labour collective, working conditions, cultural and living conditions, payment and labour discipline, main scientific and practical approaches to policy of social security implementation in the pharmaceutical sector.

Materials and methods: formal and logical method, system analysis, method of analogy and comparison, analysis of documents and results of sociological research.

Results. The article states that the introduction of the technology of social passportization of a pharmacy institution will provide a systematic approach to the calculation of the level of social development of a pharmacy and the evaluation of the indicators for achieving the standards of social passport. Comparing the final values of the indicators of social development over the years studied, we can conclude that positive effect on the social development of a pharmacy institution of implemented measures on social protection of pharmacy professionals (PhP). Due to the implementation of these measures, the overall level of social development has increased from $50 \%$ in 2015 to $74 \%$ in 2016. It has been proved that social passportization of a pharmacy institution requires adequate organizational support and the definition of the main indicators for assessing the social standards of pharmacy institutions; and these indicators have been generalized.

Conclusions. Determined by the system of assessments, obtained as a result of the analysis of the data of the non-financial reporting of the enterprise, the ranks of priorities for certain areas of social policy of the investigated pharmacy institution have been used as the necessary information base for solving the tasks of planning of its social development, formulation of recommendations for the development of social sphere and justification of socially significant measures. According to the results of the research, priority measures of further social development are identified, which solve a complex of problems of improving the existing social status of a pharmacy institution and contribute to a significant economic effect.

Key words: pharmacy institution; social protection of pharmacy professionals; social passport

\section{М. В. ЗАРІЧКОВА, О. М. ДоЛЖНІКОВА, Т. Ф. МУЗИКА}

\section{ОБІРУНТУВАННЯ СИСТЕМИ ПОКАЗНИКІВ СОЦІАЛЬНОГО ПАСПОРТА В АПТЕЧНОМУ} ЗАКЛАДІ

Метою дослідження є обгрунтування необхідності запровадження соціальних нормативів в аптечних закладах та визначення методики розрахунку соціального паспорта аптеки шляхом обчислення критеріїв, що характеризують соціальну структуру трудового колективу, умови праці та культурно-побутові умови, оплату і дисципліну праці та основних науково-практичних підходів щодо реалізації політики соціального захисту у фармацевтичному секторі.

Матеріали та методи: формально-логічний метод, системний аналіз, метод аналогії і порівняння, аналіз документів і результатів соціологічних досліджень.

Результати. У статті визначено, що впровадження технології соціальної паспортизації аптечного закладу забезпечить системний підхід до розрахунку рівня соціального розвитку аптеки та оцінки показників досягнення нормативів соціального паспорта. Порівнюючи підсумкові значення показників соціального розвитку за досліджувані роки можна зробити висновок про позитивний вплив на стан соціального розвитку аптечного закладу впроваджених заходів із соціального захисту спеціалістів фармації (СЗСФ). Завдяки впровадженню цих заходів загальний рівень соціального розвитку зріс із 50 \% у 2015 р. до 74 \% у 2016 р. Доведено, що соціальна паспортизація аптечного закладу потребує належного організаційного забезпечення та визначення основних показників, за якими проводиться оцінка соціальних нормативів аптечних закладів, та здійснене їх узагальнення.

Висновки. Визначені з використанням системи оцінок, отриманих в результаті аналізу даних нефінансової звітності підприємства, ранги пріоритетів за окремими напрямками соціальної політики досліджуваного аптечного закладу були використані як необхідна інфор- 
маційна база для вирішення завдань планування його соціального розвитку, формулювання рекомендацій щодо розвитку соціальної сфери і обгрунтування соціально значущих заходів. За результатами проведених досліджень визначені пріоритетні заходи подальшого соціального розвитку, які вирішують комплекс проблем покращення існуючого соціального стану аптечного закладу та сприяють значному економічному ефекту.

Ключові слова: аптечний заклад; соціальний захист спеціалістів фармації; соціальний паспорт

\section{М. В. ЗАРИЧКОВА, А. Н. ДоЛЖНИКОВА, Т. Ф. МуЗЫКА \\ ОБОСНОВАНИЕ СИСТЕМЫ ПОКАЗАТЕЛЕЙ СОЦИАЛЬНОГО ПАСПОРТА В АПТЕЧНЫХ УЧРЕЖДЕНИЯХ}

Целью исследования является обоснование необходимости введения социальных нормативов в аптечных учреждениях и определение методики расчета социального паспорта аптеки путем вычисления критериев, характеризующих социальную структуру трудового коллектива, условия труда и культурно-бытовые условия, оплату и дисциплину труда и основных научно-практических подходов к реализации политики социальной защиты в фармацевтическом секторе.

Материалы и методы: формально-логический метод, системный анализ, метод аналогии и сравнения, анализ документов и результатов социологических исследований.

Результаты. В статье определено, что внедрение технологии социальной паспортизации аптечного учреждения обеспечит системный подход к расчету уровня социального развития аптеки и оценки показателей достижения нормативов социального паспорта. Сравнивая итоговые значения показателей социального развития за исследуемые годы можно сделать вывод о положительном влиянии на состояние социального развития аптечного учреждения внедренных мероприятий по социальной защите специалистов фармации (СЗСФ). Благодаря внедрению этих мероприятий общий уровень социального развития вырос с 50 \% в 2015 г. до 74 \% в 2016 г. Доказано, что социальная паспортизация аптечного учреждения требует надлежащего организационного обеспечения и определения основных показателей, по которым проводится оценка социальных нормативов аптечных учреждений, и совершено их обобщение.

Выводы. Определены с использованием системы оценок, полученных в результате анализа данных нефинансовой отчетности предприятия, ранги приоритетов по отдельным направлениям социальной политики исследуемого аптечного учреждения, которые были использованы как необходимая информационная база для решения задач планирования его социального развития, формулирование рекомендаций по развитию социальной сферы и обоснования социально значимых мероприятий. По результатам проведенных исследований определены приоритетные мероприятия дальнейшего социального развития, которые решают комплекс проблем улучшения существующего социального положения аптечного учреждения и способствуют значительному экономическому эффекту.

Ключевые слова: аптечное учреждение; социальная защита специалистов фармации; социальный паспорт

\section{STATEMENT OF THE PROBLEM}

Every year the development of the social sphere of Ukraine is becoming increasingly relevant. Scientists discuss the introduction of qualitatively new forms of work organization of the social sector management bodies. Therefore, one of the priority areas is social passportization of organizations and enterprises of Ukraine, in particular pharmacy institutions.

Today, a significant number of indicators characterizing social and economic development of both the pharmaceutical sector of health industry, as a whole, and the individual pharmacy institutions are proposed in the scientific literature, but they do not allow to assess quickly, in full and unequivocally the social situation and the level of social and economic development of the subjects of the pharmaceutical market. Therefore, it is necessary to develop a system of general indicators of the state of the social sphere of the pharmaceutical sector of health industry, reflected in the social passport of a pharmacy institution, which will allow to assess objectively, compare and analyze the level of SPPhP, to identify the main trends and patterns regarding the social needs of pharmacy professionals (PhP), to indicate clearly the most acute problems of SPPhP. This makes social passportization of pharmacy institutions relevant and timely [1-3].

The relevance of the introduction of the social passport of the pharmacy institution is confirmed by the state reforms, in particular by main provisions of the Order No. 53 "On the introduction of the form of "social passport of a region, city, district" dated 30 March 2001. It is called to form a qualitatively new strategy of providing social services and solving of emerging social problems $[4,5]$. 


\section{ANALYSIS OF RECENT RESEARCHES} AND PUBLICATIONS

Problems of social provision of pharmacy professionals have been studied in scientific works by such well-known scientists as Kotvitska A. A., Mnushko Z. M., Ponomarenko M. S., Posylkina O. V., Nemchenko A. S., Tolochko V. M. and so on, but despite the significant scientific contribution of these scientists, the issues of creation and implementation of the social passport of a pharmacy institution are considered to be underreported, which makes it relevant to further elaboration of this research direction. According to the abovementioned information, the subject is relevant and requires an individual study.

\section{IDENTIFICATION OF ASPECTS OF THE PROBLEM UNSOLVED PREVIOUSLY}

According to the conducted analysis, existing forms of SPPhP are studied mainly in the published research papers on this subject, but the methodical principles of statistical analysis of the introduction of various elements of SPPhP are still not developed. It should be mentioned that according to the current legislation social passport shall be introduced at all enterprises as a statistical document that promotes effective social and legal protection of the employees.

\section{OBJECTIVE STATEMENT OF THE ARTICLE}

The purpose of the study is to justify the necessity for introduction of social passportization of pharmacy institutions and definition of basic scientific regulations on its implementation in the pharmaceutical sector of health industry. To achieve this purpose it is necessary to define a system of indicators that will reflect the main areas of social protection and social development of the staff of a pharmacy institution. The scientific novelty of the study is to determine the main indicators of social stability of a $\mathrm{PhP}$ and structure of the social passport of a pharmacy institution.

\section{PRESENTATION OF THE MAIN}

\section{MATERIAL OF THE RESEARCH}

According to the results of studies of many sources of literature, it was established that a social passport is a document that includes a set of indicators that reflect the state and prospects of social and economic development and it characterizes: the social structure of labor collective; working conditions of employees; social processes in the institution and direction of the implementation of SPPhP, etc. [2, 6, 7].

Social passportization of a pharmacy institution is a process of creating a single information resource, which allows to increase the efficiency of management of the social sphere at micro level - pharmacy institution and at the macro level - the pharmaceutical sector as a whole. Thus, one of the areas of practical implementation of social management as a social technology in the process of social and economic development of a pharmacy institution is creation of a social passport $[4,5,8]$.

According to the conducted study, with the involvement of specialists in the field of social work, we have developed and grouped social indicators of a pharmacy institution to assess the level of social development of a pharmacy. We have worked out a methodology to determine the level of social development of a pharmacy institution and have calculated the criteria for a social passport of a pharmacy institution $[1,4-7,9]$.

The positive effect of the application of the social passport proposed at work is assessed on the basis of the results of its introduction into the activity of "Vasha Apteka" pharmacy institution (Pharmaceutical company Provizor LLC, Poltava). This pharmacy institution is typical of the territory of Ukraine (in terms of production facilities, availability of personnel, etc.), its staffing consists of 5 employees $\mathrm{PhP}$ of "pharmacist" and "chemist" qualification.

Assessment of the level of social development of the pharmacy was carried out according to the method developed by A. L. Kuznetsov, which is the most universal and widely used in determining the level of social development of enterprises and institutions of various spheres of activity. This method allows to quantify the level of social development of the enterprise on the basis of integral indicators, which characterize social conditions of labour (humanization of labour) and social infrastructure of the studied institution. Despite the universality of the applied method, the calculated formulas of some of the included indexes (coefficients) were adapted taking into account the specifics of the activity of the pharmacy institution $[1,4,6,7,9,10]$. The calculation of the social passport of the researched pharmacy was performed according to the data for 2015-2016. During 2016, "Vasha Apteka" pharmacy implemented a set of measures for the implementation of the SPPhP and defined the priorities of the priorities of the strategy of social development of a pharmacy institution.

The first part of the calculating methodology for the social passport of a pharmacy was to calculate the coefficients of indicators characterizing the social structure of the labor collective, working conditions and cultural and living conditions. The social structure of the team was assessed in four coefficients [7]:

1) coefficient of qualification $\left(K_{1,1}\right)$;

2) coefficient of educational level of $\mathrm{PhP}\left(K_{1,2}\right)$;

3) coefficient of professional development of personnel $\left(K_{1,3}\right)$;

4) coefficient of stability of personnel $\left(K_{1,4}\right)$. 
Coefficient of qualification was defined as the ratio of average length of service of $\mathrm{PhP}(q)$ to the average length of service in specialty $\left(q_{u}\right)$. The peculiarity of a pharmacy institution is presence of two qualifications of $\mathrm{PhP}$ - chemists and pharmacists. As the required length of service in the specialty, for obtaining the second qualification category, for chemists constituted 3 years, and for pharmacists -5 years. The required length of service in the specialty for the post of the head of a pharmacy also constituted 5 years, so $K_{1,1}$ for a pharmacy institution $[4,8-10]$ as follows:

$$
K_{1,1}=\frac{q_{\mathrm{ch}}}{q_{u_{\mathrm{ch}}}}+\frac{q_{\mathrm{ph}}}{q_{u_{\mathrm{ph}}}}+\frac{q_{\mathrm{h} . \mathrm{ph}}}{q_{u_{\mathrm{h} . \mathrm{ph}}}}=\frac{q_{\mathrm{ch}}}{3}+\frac{q_{\mathrm{ph}}}{5}+\frac{q_{\mathrm{h} . \mathrm{ph}}}{5},
$$

where: $q_{\mathrm{ch}}$ - average length of service of chemists, $q_{u_{\mathrm{ch}}}$ - average required length of service for a chemist $\left(q_{u_{\mathrm{ch}}}=3\right)$; $q_{\mathrm{ph}}$ - average length of service of pharmacists, $q_{u_{\mathrm{ph}}}-$ average required length of service for a pharmacist $\left(q_{u_{\mathrm{ph}}}=5\right)$;

$q_{\mathrm{h} . \mathrm{ph}}$ - average length of service of a head of a pharmacy, $q_{u_{\text {h.ph }}}$ - required length of service for head of a pharmacy $\left(q_{u_{\mathrm{h} p h}}=5\right)$.

As of 2015, the pharmacy under study had a rather young team: it employed 3 pharmacists, whose average length of service constituted 1.33 years, and a chemist, whose length of service was 6 months at the end of 2015. The length of service of the head of the institution constituted 6 years. Thus, the coefficient of qualification was low: $K_{1,1_{2015}}=0.544$. Taking into account the stable structure of the team, by the end of 2016 the skill level of the personnel increased and constituted $K_{1,1_{2016}}=0.789$.

Criterion value of the coefficient of qualification $\left[K_{1,1}\right]=1$. Such a social target assumes that the level of skills of employees shall be $100 \%$ consistent with the level of their activities. The value $K_{1,1}<1$, in our case, indicates that the team is relatively young, contributing to the propensity to innovate and develop. According to these coefficients, the corresponding social targets are $H_{1,1_{2015}}=54.4$ and $H_{1,22016}=78.9$.

The coefficient of educational level of $\mathrm{PhP}$ was studied next. It is a weighted average of their educational level by categories:

$$
K_{1,2}=\frac{\sum_{i=1}^{k} B_{i} \cdot N_{i}}{N},
$$

where: $B_{i}$ - weight coefficient of the $i^{\text {th }}$ level of education;

$N_{i}$ - number of professionals with the $i^{\text {th }}$ level of education;

$N$ - the total number of employees.

We use the following weight coefficient values: $B_{i}=1$ for PhP with incomplete secondary education, $B_{i}=2$ for PhP with complete secondary edu- cation, $B_{i}=3$ for secondary vocational education, $B_{i}=4$ for secondary specialized education, and $B_{i}=5$ for degree qualified PhP. Thus, when calculating the educational level of $\mathrm{PhP}$ in the studied pharmacy for pharmacists $B_{\mathrm{ph}}=4$ weight factor was used, and $B_{\mathrm{ch}}=4-$ for chemists and the head. For the whole period of observation (2015-2016), the personnel of the studied pharmacy institution did not change, therefore the indicator of educational level of its employees was equal $K_{1,1_{2015}}=K_{1,1_{2016}}=4.4$.

We should mention that the social norm for enterprises and organizations, which require highlevel specialists, and include pharmacy institutions, constitutes $\left[K_{1,2}\right]=4[1,6,7,9]$. Therefore, the level of achievement of the target by the studied pharmacy institution is equal:

$$
H_{1,2}=\frac{K_{1,2}}{\left[K_{1,2}\right]}=1.1 .
$$

The coefficient of personnel training was calculated next as a percentage of $\mathrm{PhP}$ who upgraded their qualification in the reporting period $\left(N_{q}\right)$ to the total number of employees $N$ ):

$$
K_{1,3}=\frac{N_{q}}{N} .
$$

In 2015, none of $\mathrm{PhP}$ of the studied pharmacy institution did not undergo a refresher course, therefore $K_{1,32015}=0$. In 2016, as a result of the introduction of a set of measures for the development of a social passport and the filling of personal cards of $\mathrm{PhP}$, in addition to scheduled training for refresher courses for two PhPs, one of the pharmacists ungraded his qualification at his own discretion, therefore $K_{1,32016}=3 / 5=0.6$. The social target for this indicator is a value that reflects the general requirements for each $\mathrm{PhP}$ to attend refresher courses at least once every 5 years. Accordingly, the level of achievement of the social target for professional development of personnel for the studied years constituted:

$$
\begin{gathered}
H_{1,3_{2015}}=\frac{K_{1,3_{2015}}}{\left[K_{1,3}\right]}=0, \\
H_{1,3_{2016}}=\frac{K_{1,3_{2016}}}{\left[K_{1,3}\right]}=\frac{0.6}{0.2}=3 .
\end{gathered}
$$

Excess of the criterion value of the indicator of professional development of the personnel will increase the labour efficiency of $\mathrm{PhP}$ that will have a positive economic effect.

The coefficient of stability of the personnel was calculated as the ratio of the number of PhPs with length of service in this pharmacy institution for 5 years or more $\left(N_{c}\right)$ to the total number of employees:

$$
K_{1,4}=\frac{N_{c}}{N} .
$$


The social target of stability of personnel is the value $\left[K_{1,4}\right]=0.8$ that allows the natural process of rejuvenation of the staff at the level of $20 \%$ [7]. As we have already noted, the team of the studied pharmacy was rather young and by the end of 2015 only one of $\mathrm{PhP}$ had worked for more than 5 years, therefore $K_{1,42015}=0.20$. As of 2016 it was $K_{1,42016}=2 / 5=0.40$.

Thereafter, the indicator of achievement of the social target of stability of personnel constituted:

$$
\begin{gathered}
H_{1,4_{2015}}=\frac{K_{1,4_{2015}}}{\left[K_{1,4}\right]}=0.25, \\
H_{1,4_{2016}}=\frac{K_{1,4_{2016}}}{\left[K_{1,4}\right]}=\frac{0.4}{0.8}=0.50 .
\end{gathered}
$$

The evaluation of working conditions, cultural and living conditions in a pharmacy institution was carried out according to three indicators $[1,6,7]$ :

1) coefficient of compliance of workplaces with licensing conditions $\left(K_{21}\right)$;

$2)$ the coefficient of provision of sanitary conditions and premises $\left(K_{2,2}\right)$;

3) coefficient of conditions of manufacturing environment $\left(K_{23}\right)$.

The coefficient of work permit compliance with the licensing conditions was calculated as the ratio of the number of workplaces corresponding to the conditions of labour protection $\left(M_{0}\right)$, to the total number of workplaces $(M)$. The social target of this indicator $\left[K_{2,1}\right]=1$ indicates the need to match $100 \%$ of the pharmacy workplaces with the conditions of labor protection, therefore, in our study, this indicator met the target $K_{2,11_{2015}}=K_{2,12_{2016}}=1$.

The coefficient of provision of sanitary and hygienic premises was calculated according to the following formula:

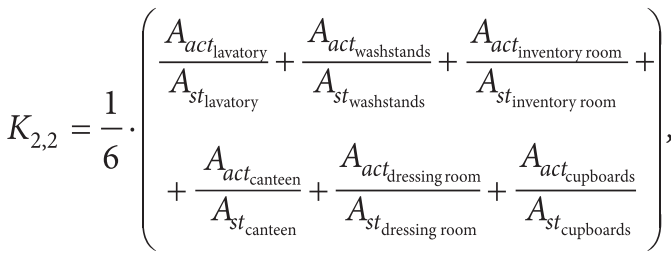

where: $A_{s t_{i}}$ - standard number of sanitary and hygienic premises or equipment of $i^{\text {th }}$ kind;

$A_{\text {acti }}$ - their actual number;

$n-$ number of types of sanitary and hygienic equipment or premises.

According to licensing conditions in the pharmacy, which does not involve the manufacture of medicinal products (MP), but only the sell of the finished MP, under sanitary regulations taking into account the area of the institution and the number of employees there should be a bathroom, hand sinks, a separate storage room for cleaning equipment, a room for changing clothes and storing work clothes with separate lockers for each employee, a separate room for meals by staff. As of 2015, in the studied pharmacy institution, there was one bathroom with one hand sink, a dressing room with three clothes closets, a separate living room for household equipment. Thus, the coefficient of availability of sanitary conditions in this pharmacy was: $\mathrm{K}_{2,22015}=0.767$.

During 2016, as part of the implementation of a set of measures to introduce a social passport and to increase SPPhP, which also included improvement of the living conditions of PhPs at their workplaces, a pharmacy room was equipped with a room for meals and a renovated wardrobe room, which resulted in the improvement of sanitary labour conditions and constituted: $\mathrm{K}_{2,22016}=0.967$ that is, the level of achievement of the social indicator increased from $76.7 \%$ in 2015 to $96.7 \%$ in 2016 and almost reached the social target.

The coefficient of conditions of manufacturing environment includes presence in a pharmacy institution of the rooms for rest, the number of seats in the canteen, etc. and it is calculated according to the following formula:

$$
K_{2,3}=\frac{1}{n} \sum\left(\frac{B_{a c t_{i}}}{B_{s t_{i}}}\right),
$$

where $B_{s t_{i}}$ - standard number of objects of manufacturing environment of the same type;

$B_{a t_{i}}$ - their actual number;

$n$ - number of types of objects of manufacturing environment, which subject to registration.

We should mention that as of the end of 2015 in the studied pharmacy there was a room for the rest of the employees, but it did not include the place for meals. Due to the re-planning in 2016, the room was equipped with three places for meals. Therefore, in 2015 the conditions of the working life of the $\mathrm{PhP}$ of the studied pharmacy institution constituted $K_{2,32015}=0.5$, and in 2016 it became $K_{2,32016}=0.8$.

The next section of the social passport describes the state of payment and labour discipline in a pharmacy institution, and it is described by three indicators $[1,7]$ :

1) the ratio of the average monthly salary of employees of the institution and within the region $\left(K_{3,1}\right)$;

2) the coefficient of the average salary ratio of the head of the institution to the low-paid category of employees $\left(K_{32}\right)$;

$3)$ the ratio of the level of labour discipline $\left(K_{3,3}\right)$.

The coefficient $K_{3,1}$ is a ratio of average monthly salary of $\mathrm{PhP}$ of the lowest-paid category of staff $\left(\bar{S}_{c h}\right)$ to the average salary in the region for the same period $\left(\bar{S}_{\text {region }}\right)$ :

$$
K_{3,1}=\frac{\bar{S}_{c h}}{\bar{S}_{\text {region }}} .
$$

Social target of this indicator is value $\left[K_{3,1}\right]=1$. According to the State Statistics Committee, the 
average salary in Poltava region in 2015 amounted to $3795.50 \mathrm{UAH}$, in $2016-4625.83 \mathrm{UAH}$. For the studied pharmacy institution, the lowest-paid category of employees is the pharmacists whose average monthly salary in 2015 amounted to $1500.00 \mathrm{UAH}$, and in $2016-3200.00 \mathrm{UAH}$. Accordingly, $K_{3,1_{2015}}=$ $=0.395, K_{3,1_{2016}}=0.692$. Thus, the level of achievement of the social target of the ratio of minimum salary of the pharmacy institution and the average salary in the region during the observation period increased from $39.5 \%$ to $69.2 \%$.

The social target for the ratio of the salary of the lowest-paid category of $\mathrm{PhP}$ to the salary of the head of the institution is the ratio of 1:8. Therefore, the corresponding coefficient in the social passport was calculated according to the following formula [7]:

$$
K_{3,3}=\frac{8 \cdot \bar{S}_{c h_{\min }}}{\bar{S}_{h . p h}},
$$

where: $\bar{S}_{c h_{\min }}$ - average monthly salary of low-paid employees;

$\bar{S}_{h . p h}$ - average salary of the head of the pharmacy institution for one month of the accounting period.

The average monthly wage of the head of the studied pharmacy in 2015 constituted $3000.00 \mathrm{UAH}$, while in 2016 it increased to $5000.00 \mathrm{UAH}$. Thus, $K_{3,22015}=4$, and $K_{3,22016}=5.12$.

The coefficient of the level of labour discipline is the ratio between the number of men-days lost as a result of absenteeism, delays or other violations of labour discipline $(P)$, and the total number of employees of the institution $(N)$ :

$$
K_{3,3}=\frac{P}{N} \text {. }
$$

According to many sources of literature it is suggested to use value $\left[K_{3,3}\right]=0.33$ as the most common social target. For this coefficient, unlike other indicators of a social passport, smaller values indicate more significant social achievements, therefore, the level of achievement of the social target for the indicator of the level of labour discipline is more appropriate to count as the inverse ratio:

$$
H_{3,3}=\frac{\left[K_{3,3}\right]}{K_{3,3}} \text {. }
$$

The introduction of a set of measures to improve SPPhP in the studied pharmacy facility allowed to reduce the loss of working time as a result of violations of labour discipline from 1.6 men-days in 2015 to 0.7 men-days in 2016. That is, the coefficients of the level of labour discipline and the level of achievement for the two comparable periods compiled: $K_{3,3_{2015}}=0.32, H_{3,3_{2015}}=1.03$ and $K_{3,3_{2016}}=0.14$, $H_{3,32016}=2.36$.

In the second part of the social passport, the state of the objects of social infrastructure of the pharmacy was evaluated on the basis of five indicators $[1,6,7]$ :

1) the coefficient of availability of employees' accommodation $\left(K_{4,1}\right)$;

2) the coefficient of availability of institutions for children $\left(K_{4,2}\right)$;

$3)$ the coefficient of availability of therapeutic and recreational activities $\left(K_{4,3}\right)$;

4) the coefficient of availability of cultural, educational events $\left(K_{4,4}\right)$; $\left(K_{4,5}\right)$.

$5)$ the coefficient of availability of sports events

We should mention that in the studied pharmacy institution, before the introduction of the proposed set of measures for SPPhP, the achievement of all these indicators of social infrastructure was at zero level. Unfortunately, such a state of social infrastructure is typical for the vast majority of domestic pharmacies. In some cases, pharmacies that are part of large pharmacy networks, have desire and ability to compensate, at least partially, for housing rent for employees, who come from other regions, for therapeutic and recreational activities, and to take care of cultural leisure activities of the employees. We shall admit that the development of social infrastructure for pharmacy institutions of Ukraine remains the least developed direction, although, according to the conducted experiment, at least some of its elements are financially feasible even for small pharmacies [2, 3].

The coefficient of availability of employees' accommodation was calculated as the product of two components, the first of which $\left(\mathrm{P}_{4,1,1}\right)$ characterized the level of accommodation availability for $\mathrm{PhP}$, who were invited from other regions, and the second one $\left(\mathrm{P}_{4,1,2}\right)$ describes living conditions of all PhPs of a pharmacy:

$$
K_{4,1}=P_{4,1,1} \cdot P_{4,1,2} \text {. }
$$

In turn, $P_{4,1,1,1_{2016}}=0.147$ and $P_{4,1,22016}=1.385$, therefore, the coefficient of accommodation availability for pharmacy employees constitutes: $P_{4,12016}=0.147 \cdot 1.385=0.203$.

Next we calculated the coefficient of availability of institutions for children of $\mathrm{PhP}$ of this pharmacy according to the formula:

$$
K_{4,2}=N_{\text {child }} / N_{\text {child }}^{\mathrm{e}} \text {, }
$$

where: $N_{\text {child }}^{\mathrm{e}}$ - the number of children of the employees, who are provided with places in children's institutions at the expense of the pharmacy; $N_{\text {child }}$ - the total number of children of the employees, who need a place in children's institutions.

The social target for this indicator is $\left[K_{4,2}\right]=1$. We should note that the improvement of this aspect of SPPhP was not included in the program of measures implemented in the pharmacy institution, therefore $K_{4,22015}=K_{4,22016}=0$. 
The coefficient of availability of therapeutic and recreational activities was calculated according to the formula:

$$
K_{4,3}=\frac{1}{n} \sum\left(C_{\text {actual }_{i}} / C_{\text {normative }_{i}}\right),
$$

where: $C_{\text {actuali }}$ and $C_{\text {normative }}$ - actual and normative number of men-beds in a healthcare institution of the $i^{\text {th }}$ type, respectively;

$n$ - number of types of healthcare institutions.

In 2015 in the studied pharmacy there was no funding for such activities, and in 2016 in connection with the introduction of a social passport in the pharmacy to improve SPPhP, a partial payment for medical and health services of employees in case of need was provided. Two PhPs took this opportunity, one of them was reimbursed with $10 \%$ of the costs for dental procedures, and the other one - with a third of the cost for therapeutic and recreational treatment. Thus, $K_{4,32015}=0, K_{4,32016}=0.125$, the level of achievement of the social target, which constituted $\left[K_{4,3}\right]=1$ with the provision of $\mathrm{PhP}$ with therapeutic and recreational activities, respectively: $H_{4,32015}=0, H_{4,32016}=12,5 \% / 100 \%=0.125$.

The coefficient of availability of cultural, educational, religious activities was calculated as follows $[1,7]$ :

$$
K_{4,4}=\frac{1}{n} \sum\left(K_{\text {actual }_{i}} / K_{\text {normative }_{i}}\right),
$$

where: $K_{\text {actual } i}$ and $K_{\text {normative }}$ - actual and normative number cultural, educational, religious activities of $i^{\text {th }}$ type;

$n$ - number of types of such activities.

In 2015 the pharmacy institution did not pay attention to the employees' leisure time, in 2016 in connection with the introduction of the social passport of the pharmacy in order to improve SPPhP, it was decided to conduct three cultural events with the payment of half the cost of tickets for theatrical performance and the concert, and full ticket prices for circus performances for children of PhPs. Thus, $K_{4,4_{2015}}=0, K_{4,4_{2016}}=0.667$.

The coefficient of availability of sports events was calculated according to the formula similar to the previous two formulas:

$$
K_{4,5}=\frac{1}{n} \sum\left(P_{\text {actual }_{i}} / P_{\text {normative }_{i}}\right),
$$

where: $P_{\text {actual } i}$ and $P_{\text {normative } i}$ - actual and normative number of sports events of $i^{\text {th }}$ type;

$n$ - number of types of sports events.

In 2016 within the framework of the implementation of the social package for PhP, $50 \%$ of the expenses for the swimming pool of one of the PhPs was compensated; in 2015 no attention was paid to the problem of holding sports events for PhP. Thus, $K_{4,52015}=0, K_{4,52016}=0.5$.
The calculated coefficients for the studied pharmacy institution as of 2015-2016 were filled into the social passport of the pharmacy. The average levels of achievement of social targets were calculated for each of the section of the social passport; they determined the overall level of social development of the pharmacy. The calculation was carried out in compliance with the recommendations of A. L. Kuznetsov's methodology, according to which the indexes of achievement of social targets were averaged, all values $H_{i, j}>1$ constituted one. General level of social development of the pharmacy was assessed as the average of the indexes of achievement of social targets in four sections of the social passport. By comparing the final values for 2015-2016 we can conclude that the implemented in 2016 activities on SPPhP influenced positively on the state of social development of the pharmacy institution and resulted in general increase in the social development of the studied pharmacy from $50 \%$ in 2015 to $74 \%$ in 2016. Comparison of the indicators of the level of social development of the studied pharmacy for each of the four sectors of social policy before and after the introduction of the proposed activities on SPPP is shown in Table $[1,6,7]$.

According to the indicators of achievement of social targets, the ranks of priority of directions of social development of the pharmacy institution were determined. The social policy of the pharmacy institution shall be improved according to these indicators.

Applying the system of assessments obtained as a result of the data analysis of non-financial reporting of the enterprise, the ranks of priorities of certain areas of social policy of the investigated pharmacy institution were determined and used as necessary database to solve the tasks of planning the social development of the pharmacy institution, formulation of recommendations for the development of the social sphere and justification of socially significant actions.

According to the results of the conducted study, the priority directions of social development of the studied pharmacy institution were lined up in the following order:

1. Improvement of objects of social infrastructure, financing of medical, preventive and recreational, sports, cultural and educational events.

2. Increase of the level of social structure of the personnel, with particular attention paid to the stability of personnel, prevention of personnel turnover.

3. Raise in payment and labour discipline.

4. Improvement of cultural and material working conditions.

The determined procedure is only a formal proposal to owners and management of the pharmacy to draw attention to the complex of problems of 


\section{ESTIMATION OF THE RESULTS OF SOCIAL PASSPORT INTRODUCTION IN “VASHA APTEKA” PHARMACY INSTITUTION}

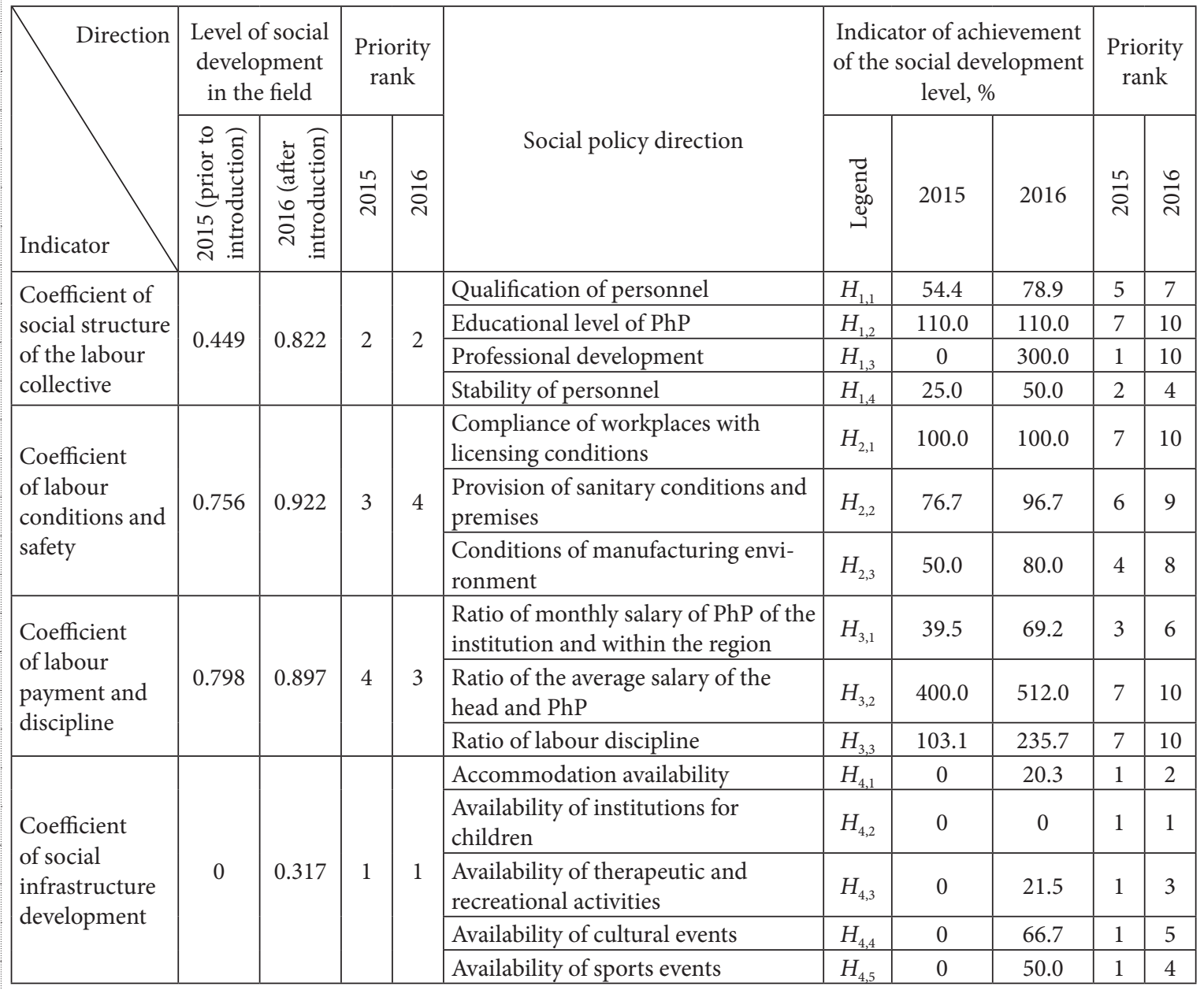

social development, the solution of which will lead to significant economic effect.

Thus, according to the results of implementation of the proposed measures for SPPhP in a pharmacy, we can state the positive impact of these innovations on the level of its social development. The most significant improvements were made by the indicators of manufacturing environment and the professional development of PhP. There is a significant improvement in the level of social targets in terms of the status of social infrastructure, although this direction of social policy of the pharmacy institution remains the weakest and needs further development.

Summing up, we can note that on the basis of social passportization of pharmacy institutions there is an opportunity to compare social passport indicators with the criterion social values, to identify the threats to social and economic safety of the pharmacy institution and to create conditions for the development of justified strategy for social de- velopment, both as separate pharmacy establishments and healthcare system as a whole.

\section{CONCLUSIONS AND PROSPECTS FOR FURTHER RESEARCH}

1. The article for the first time suggests scientific and methodical approaches for the development of a system of general indicators of the state of the social sphere of the pharmaceutical sector of health industry, which are reflected in the social passport of a pharmacy institution, which allows to evaluate, compare and analyze objectively the level of SPPhP, to identify the main trends and regularities regarding PhP's social needs, to clearly identify the most acute problems of SPPhP.

2. As a result of introduction of a social passport in "Vasha Apteka" pharmacy we can state that there is social and economic effect, which is resulted in the improvement of SPPhP and the enhancement of financial and economic effect 
of the pharmacy. In general, the overall level of social development of the pharmacy institution can be defined as the average (0.50) in 2015 and higher than the average (0.74) in 2016.

3. The ranks of directions of certain areas of the social policy of the pharmacy institution are defined; they are used for solving the tasks of planning the social development of the pharmacy institution, formulating of recommendations for the development of the social sphere and justifying the complex of necessary measures.

Conflict of interests: authors have no conflict of interests to declare.

\section{REFERENCES}

1. Захаров, Н. Л. Управление социальным развитием организации : учебник / Н. Л. Захаров, А. Л. Кузнецов. - М. : Инфра-М, 2006. - 272 с.

2. Zarichkova, M. V. Formation of the system of indicators and the information content of the social passport of pharmacy institutions / M. V. Zarichkova // Соціальна фармація в охороні здоров'я. - 2017. - Т. 3, № 2. - C. 49-59. https://doi.org/10.24959/sphhcj.17.78

3. Zarichkova, M. V. Theoretical substantiation of the necessity to implement social certification of pharmacy institutions / M. V. Zarichkova // Управління, економіка та забезпечення якості в фармації. - 2017. № 1 (49). - С. 34-41. https://doi.org/10.24959/uekj.17.8

4. Про впорядкування умов оплати праці працівників закладів охорони здоров'я та установ соціального захисту населення : Наказ Міністерства праці та соціальної політики України та Міністерства охорони здоров’я України від 5 жовтня 2005 р. № 308/519. - Режим доступу : https://ips.ligazakon. net/document/view/RE11489?an=1978\&q (дата звернення: 24.12.2018).

5. Про запровадження в дію форми «Соціальний паспорт регіону, міста, району» : Наказ Державного комітету молодіжної політики, спорту і туризму України та Українського державного центру соціальних служб для молоді від 30. 05. 2001 р. № 53. - Режим доступу : http://www.uazakon.com/ document/spart29/inx29660.htm (дата звернення: 24.12.2018).

6. Иванычева, Т. А. Социальный паспорт организации - элемент социальных технологий управления социальным развитием // Перспективы развития науки и образования: сборник научных трудов по материалам Международной заочной научно-практической конференции 30 января 2014 г. : в 15 частях. Ч. 6. - Тамбов: Бизнес-Наука-Общество, 2014. - С. 61-62.

7. Кузнецов, А. Л. Социальные стратегии предприятия / А. Л. Кузнецов. - Ижевск : Изд-во ИЖГТУ, 2000. - 126 c.

8. Деякі питання діяльності територіальних центрів соціального обслуговування (надання соціальних послуг) : постанова Кабінету Міністрів України від 29.12.2009 р. № 1417. - Режим доступу : http:// www.zakon.rada.gov.ua (дата звернення: 24.12.2018).

9. Довідник кваліфікаційних характеристик професій працівників. Випуск 78. Охорона здоров’я : Наказ Міністерства охорони здоров’я України від 29 березня 2002 р. № 117. - Режим доступу : https://ips.ligazakon.net/document/view/MOZ5907?an=1854\&q (дата звернення: 24.12.2018).

10. Про затвердження Ліцензійних умов провадження господарської діяльності з виробництва лікарських засобів, оптової та роздрібної торгівлі лікарськими засобами, імпорту лікарських засобів (крім активних фармацевтичних інгредієнтів) : постанова Кабінету Міністрів України від 30 листопада 2016 р. № 929. - Режим доступу : https://ips.ligazakon.net/document/view/KP160929?an=1 (дата звернення: 24.12.2018).

\section{REFERENCES}

1. Zakharov, N. L., Kuznetcov, A. L. (2006). Upravlenie sotcialnym razvitiem organizatcii: uchebnik. Moscow: Infra-M, 272.

2. Zarichkova, M. V. (2017). Formation of the system of indicators and the information content of the social passport of pharmacy institutions. Social'na farmaciâ v ohoronì zdorov'â, 3(2), 49-59. https://doi.org/10.24959/ sphhcj.17.78

3. Zarichkova, M. V. (2017). Theoretical substantiation of the necessity to implement social certification of pharmacy institutions. Upravlinnâ, ekonomika ta zabezpečennâ âkostì v farmacï, 1 (49), 34-41. https://doi. org/10.24959/uekj.17.8

4. Nakaz Ministerstva pratsi ta sotsialnoi polityky Ukrainy ta Ministerstva okhorony zdorovia Ukrainy vid 5 zhovtnia 2005 r. № 308/519. (2005). Pro vporiadkuvannia umov oplaty pratsi pratsivnykiv zakladiv okhorony zdorovia ta ustanov sotsialnoho zakhystu naselennia. - Available at: https://ips.ligazakon.net/document/view/ RE11489?an=1978\&q

5. Nakaz Derzhavnoho komitetu molodizhnoi polityky, sportu i turyzmu Ukrainy ta Ukrainskoho derzhavnoho tsentru sotsialnykh sluzhb dlia molodi vid 30.05.2001 r. № 53. (2001). Pro zaprovadzhennia v diiu formy 
«Sotsialnyi pasport rehionu, mista, raionu». - Available at: http://www.uazakon.com/document/spart29/ inx29660.htm

6. Ivanycheva, T. A. (2014). Perspektivy razvitiia nauki i obrazovaniia: sbornik nauchnykh trudov po materialam mezhdunarodnoi zaochnoi nauchno-prakticheskoi konferentcii (30.01.2014). Tambov: Biznes-NaukaObshchestvo, 61-62.

7. Kuznetcov, A. L. (2000). Sotcialnye strategii predpriiatiia. Izhevsk: Izd-vo IZhGTU, 126.

8. Postanova Kabinetu Ministpiv Ukpainy vid 29.12.2009 p. №1417. (2009). Deiaki pytannia diialnosti tepytopialnykh tsentpiv sotsialnoho obsluhovuvannia (nadannia sotsialnykh posluh). - Available at: http://www. zakon.rada.gov.ua

9. Nakaz Ministerstva okhorony zdorovia Ukrainy vid 29 bereznia 2002 r. № 117. (2002). Dovidnyk kvalifikatsiinykh kharakterystyk profesii pratsivnykiv. Vypusk 78. Okhorona zdorovia. - Available at: https://ips. ligazakon.net/document/view/MOZ5907?an=1854\&q

10. Postanova Kabinetu Ministriv Ukrainy vid 30 lystopada 2016 r. № 929. (2016). Pro zatverdzhennia Litsenziinykh umov provadzhennia hospodarskoi diialnosti z vyrobnytstva likarskykh zasobiv, optovoi ta rozdribnoi torhivli likarskymy zasobamy, importu likarskykh zasobiv (krim aktyvnykh farmatsevtychnykh inhrediientiv). - Available at: https://ips.ligazakon.net/document/view/KP160929?an=1

Адреса для листування:

61001, м. Харків, пл. Захисників України, 17.

Надійшла до редакції 18.01.2019 p.

Тел. (057) 732-75-58. E-mail: uef-ipksf@.nuph.edu.ua.

Інститут підвищення кваліфікації спеціалістів фармації Національного

фармацевтичного університету

Зарічкова М. В. (ORCID - https://orcid.org/0000-0001-7980-5669)

Должнікова О. М. (ORCID - https://orcid.org/0000-0003-0961-0158)

Музика Т. Ф. (ORCID - https://orcid.org/0000-0002-7516-2296) 